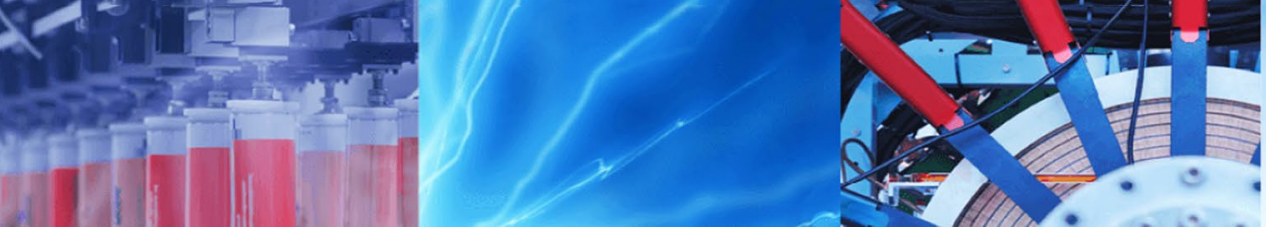

Research Article

\title{
Landscape evolution in ferruginous geosystems of the Iron Quadrangle, Brazil: a speleological approach in a biodiversity hotspot
}

\author{
Mauro Gomes $^{1}\left[\right.$ [D Rodrigo Lopes Ferreira ${ }^{2}$ (D) Úrsula de Azevedo Ruchkys ${ }^{3}[$
}

(c) Springer Nature Switzerland AG 2019

\begin{abstract}
Natural subterranean caves represent a complex system, and studying them requires a holistic perspective considering their integration with the landscape. The vegetal cover around caves plays a key role in the energy input to the subterranean environment, mainly in caves associated with ferriferous formations, since the primary production by photosynthetic organisms is absent in such environments due to the permanent darkness. The current research aimed to characterize transitions in the composition of the surrounding landscape of a set of 235 ferruginous caves in the Iron Quadrangle, (Minas Gerais, Brazil) from 1984 to 2015, using information of remote sensors, geoprocessing techniques and concepts of landscape ecology. The analysis of landscape composition indicated a significant decrease in the conservation level of the study area $\left(530 \mathrm{~km}^{2}\right)$, which has lost $22.14 \%$ of the original vegetal cover. The conversion of native vegetation into anthropized areas in this period eliminated almost the entire protection radius of $15 \%$ of the caves known in the region, as well as committed the surrounding area of other $32 \%$. This study demonstrated the need to develop scientific researches that relate the cave fauna and vegetal cover surrounding the caves, as well as the consequences that anthropic activities may cause to the subterranean environment.
\end{abstract}

Keywords Ferruginous caves · Landscape composition · Iron Quadrangle · Ferruginous geosystems

\section{Introduction}

The consumption of steel increased significantly in the last decades $[21,77]$. Such great demand, mainly by China, has been encouraging countries which hold natural reserves of iron ore, essential component for the steel manufacture, to increase their production as never before [73]. However, the production of steel without previous treatments requires ore with high iron concentration, and that is found in only a few countries. In this scenario, Brazil and Australia stand out for holding the largest reserves of economically feasible ore in the world [73]. The mineral extractive industry has deserved a historically important role in the Brazilian trade balance. In 2017, it represented $1.4 \%$ of all the Gross Domestic Product of the country, with iron ore responsible for $62 \%$ of the mineral substances exported by Brazil [42].

However, the economic development is accompanied by several types of impacts affecting not only the society welfare $[60,72]$, but also the natural resources. The vegetal cover of areas with occurrence of iron ore presents highly specialized species, with high degrees of endemism that currently are severely threatened $[8,24,44,45,69$, 70]. Disturbances caused by iron mining are also observed at larger scales, altering aquatic and terrestrial environments, as pointed by Vama et al. [76], González et al. [34],

$\triangle$ Mauro Gomes, mauro.gomes@icmbio.gov.br; Rodrigo Lopes Ferreira, drops@dbi.ufla.br; Úrsula de Azevedo Ruchkys, tularuchkys@ yahoo.com.br | ${ }^{1}$ Centro Nacional de Pesquisa e Conservação de Cavernas, Instituto Chico Mendes de Conservação da Biodiversidade - ICMBio, Av. Montreal, s/no - Bairro Jardim Canadá, Nova Lima, MG 34.007-720, Brazil. ${ }^{2}$ Laboratório de Biologia Subterrânea, Departamento de Biologia, Universidade Federal de Lavras - UFLA, Av. Central, s/n - Campus Universitário, Lavras, MG 37.200-000, Brazil. ${ }^{3}$ Departamento de Cartografia, Instituto de Geociências, Universidade Federal de Minas Gerais - UFMG, Av. Antônio Carlos, 6627, Pampulha, Belo Horizonte, MG 31270-901, Brazil. 
Fernandes et al. [25] and de Neves et al. [15]. Regarding terrestrial environments, discussions on the impacts to the Brazilian speleological heritage caused by the exploration of iron ore have become of greater importance in recent years $[3,16,65]$, specially after the alterations in the federal legislation that started allowing the suppression of caves provided that specific studies have been conducted [7].

The Brazilian speleological heritage has the caves as its most expressive representative [2], although it is important to highlight that such heritage is not restricted to the caves and their intrinsic attributes. It also represents all the heterogeneity of biotic and abiotic, subterranean and surface elements associated with such features. Studies involving subterranean natural caves must be conducted under a holistic perspective considering their integration with the landscape, the dynamics of natural and anthropic processes and the consequent impacts caused by such interactions. Anthropic actions like urbanization and industrialization, damming of watercourses, agriculture and mining may alter or potentialize the effects of such processes, causing negative impacts to the speleological heritage, sometimes irreversible [1].

Several regions of the Brazilian territory that have records of caves handle with the pressure imposed by anthropic actions, specially the Ferruginous Geosystems (FGs). Such term is used to refer to the spatial units whose lithologic substrate consists in ferruginous lithotypes, such as banded iron formations (BIFs) or itabirites, cangas, jaspilites, ferruginous metadiamictites, ferruginous phyllites, among others [16].

In Brazil, FGs are restricted to a few regions in the states of Minas Gerais (Iron Quadrangle, eastern border of the Serra do Espinhaço and Peixe Bravo river valley), Pará (Serra de Carajás), Bahia (São Francisco river valley) and Mato Grosso do Sul (Urucum plateau) [16]. Although such systems are spatially restricted, they have high potential for the occurrence of caves, with more than 2000 records until $2015[58,59]$. The caves located in the Iron Quadrangle have developed in the inner part of the ferruginous breccias, within the BIF, and at contact points between them [66]. In general, caves are dry and small and many of them have only one small chamber with conduits tapering into small channels, irregular sections and with pillars, pendants and skylights $[9,58,59]$. Such canaliculi represent one of the main characteristics of this type of cave, which form an extensive network of interstitial spaces, interconnecting macro-, meso- and micro-caves [28].

These void networks allow the storage and circulation of water, thus favoring the coexistence of terrestrial and aquatic fauna that move from the surface to the innermost subterranean habitats. The evident diversity of the species found in this kind of cave include relict and endemic species [28]. From a biological point of view, one of the main characteristics of this type of cave is the high species richness when compared to those with similar dimensions associated with other lithologies [67]. Subterranean communities of such environments are mainly supported by roots from external trees and shrubs that grow along the interstices in the rock reaching the galleries of the cave [28]. The bat guano and vegetal organic matter deposits carried into the caves by the wind or water also represent important food sources [26]. The strict relationship between the composition of food resources of these communities and the vegetal cover around the caves highlights the key role of vegetation regarding the maintenance of such habitats. Thus, this paper aims to analyze and characterize changes in land use and land cover (LULC) around the Iron Quadrangle ferruginous caves from 1984 to 2015. Therefore, it is expected that the results achieved by this research will encourage the development of specific works on the correlation between the characteristics of the vegetation cover surrounding the caves and the subterranean ecosystems of the FGs.

\section{Description of the study area}

The study area (Fig. 1) is located at the Southeastern Brazil in the state of Minas Gerais, in the western portion of the Iron Quadrangle which is in the southernmost region of the Biosphere Reserve of Serra do Espinhaço [75]. Its limits include 12 municipalities and an approximate area of $530 \mathrm{~km}^{2}$. The Iron Quadrangle [19] is considered one of the largest producers of iron ore in the world and has been playing a leading role in the development of Brazil since the eighteenth century due to the mineral exploration [66].

The region sits on the transition between the Brazilian Savannah and Atlantic Forest biomes, two hot spots of the world biodiversity [56], whose territory presents both native vegetation and anthropic activities. The seasonal semideciduous forest and gramineous-woody savannah are predominant in the region, and according to Solá et al. [68], the region represents an island of gramineous-woody savannah surrounded by a forest matrix in inferior topographic positions in the regional landscape.

The FGs of the central region of Minas Gerais are constituted by Archaean (Rio das Velhas Supergroup) and Proterozoic (Minas Supergroup and Itacolomi Group) terrains [63]. The basement of the Minas Supergroup consists of amphibolite facies metamorphic granite gneiss terrains and the Rio das Velhas greenstone belt, and the sequence of this Supergroup, from the bottom to the top, is represented by the clastic Caraça Group, BIFs of the Itabira Group, Piracicaba Group and the Sabará Group [64]. 
Fig. 1 Map of the study area in the Iron Quadrangle, Minas Gerais, Brazil

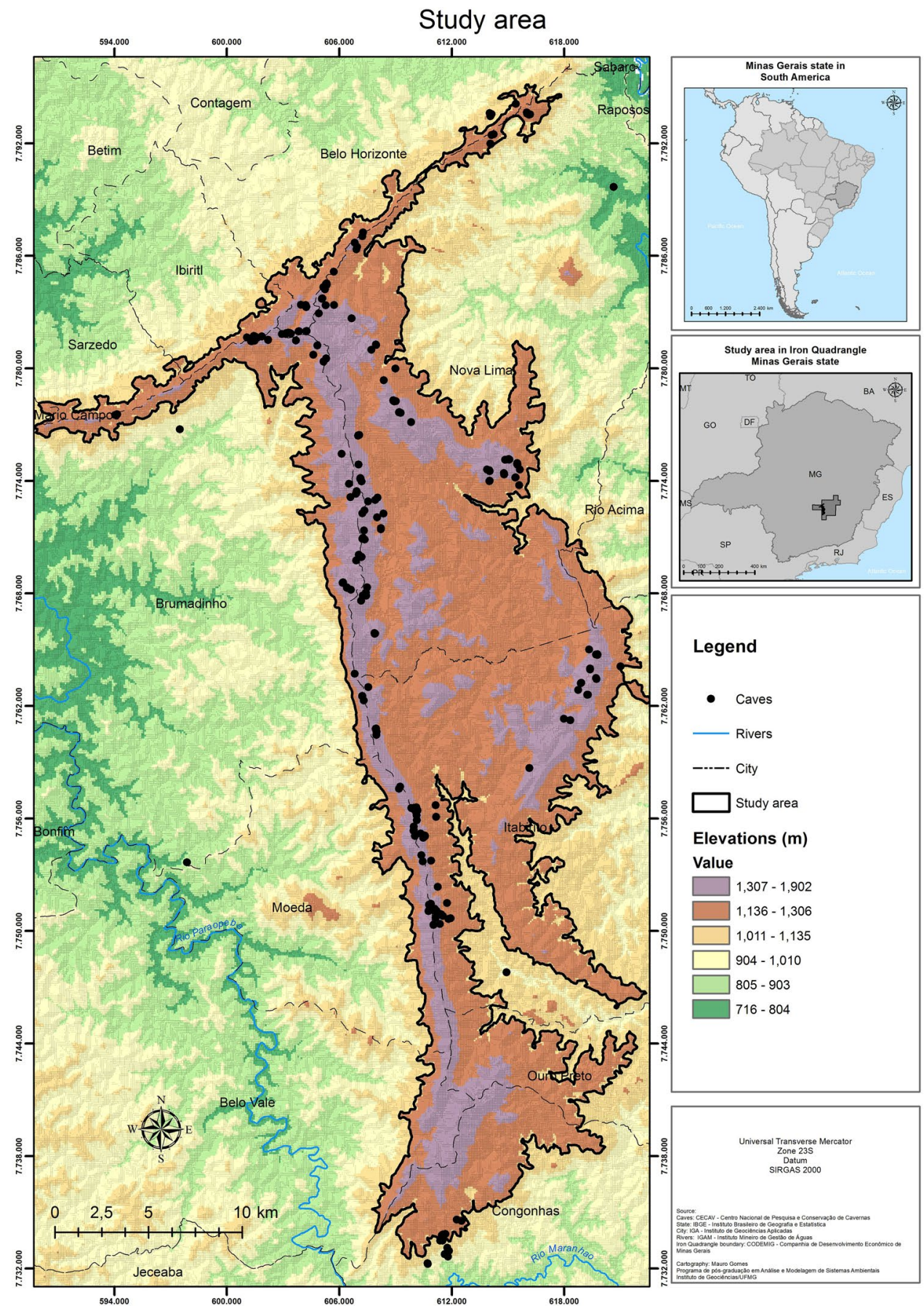

Regarding speleology, the map of potential occurrences of caves in Brazil [46] indicates that $71 \%$ of the study area presents "high potential." Such scenario is confirmed by the 235 natural caves registered in the dataset of National Center of Research and Cave Conservation, CECAV [11]. A recent study published by this institution [10] classified the study area as priority for the conservation of the Brazilian speleological heritage and therefore is supposed to be the target of actions toward the creation or improvement of protected areas, control of deforestation, inspection, monitoring and environmental and patrimonial education.

Haplic Cambisol predominates due to its complex geological structure formed by metavulcanic and metasedimentary rocks basically constituted by the quartzites of Moeda Formation (Caraça Group) and the itabirites of Cauê Formation (Itabira Group). However, dark red Argisols and Litholic soils are also observed [23]. The relief is marked by wide and smooth hills of convex geometry with rounded or flattened tops, with little alluvial sedimentation, 
presenting altitudes between 1200 and $1300 \mathrm{~m}$ and mean drainage density with dendritic pattern [14]. The climate in the region has a great influence on the complex of hills that delimit the Iron Quadrangle, generating local areas with different morphoclimatic systems inserted in the zone of Central Brazil Tropical Climate [39] with monthly mean temperature between 16.5 and $23.2^{\circ} \mathrm{C}$ [5]. Dry periods are concentrated in the winter and wet periods in the summer [49].

\section{Materials and methods}

The process of conversion of the vegetal cover into anthropized areas around the ferruginous caves was observed in terms of variations occurred in the size of areas occupied by such thematic classes, comparing satellite images of the years of 1984 and 2015, as well as in the spatial location of such alterations through time. LULC classification and change detections were undertaken using a scene 218-74 from Landsat Thematic Mapper (TM), date June 06, 1984 and Landsat Operational Land Imager (OLI), date August 31, 2015, both images with $30 \mathrm{~m}$ of spatial resolution. A color composition (RGB) with near infrared, red and green bands (543 - OLI e 432 - TM) was adopted to better distinguish the different vegetation patterns found in the images and to elaborate the LULC map. The recognition of patterns and homogeneous objects was made through supervised classification by region growth, using the Battacharya classifier of the software SPRING [43]. The legend adopted was defined by adaptations of the proposal of the Basic System of Classification of Land Coverage and Use of the Brazilian Institute of Geography and Statistics-IBGE, due to the specificity of the analysis [41]. The classification of Ribeiro and Walter presented in the Technical Manual of the Brazilian Vegetation of IBGE [40, p. 44] was used for classes related to the natural vegetation. The definition of classes in the sample was made based on field observations, previous works conducted in the region [32] and comparative analysis with images available in Google Earth [35]. The representation of vegetal cover was categorized into three groups: herbaceous vegetation, shrubs and trees. Classes related to land use were represented by the mining areas, urban areas, forestry, pasture and exposed soil.

After processing the images, they were exported to ArcGIS for vectorization and preparation of the final maps. At this stage, data related to the changes detected were also quantified using the Vector-based Landscape Analysis Tools-V-LATE 2.0 beta, to obtain landscape metrics (area, size and number of patches and distance between patches and points). LULC maps were combined by means of the map algebra using a sum operation (pixel to pixel) that allowed analyzing the transition that occurred in the studied period. The interpretation of combinations allowed not only identifying the places where the original vegetal cover was replaced by anthropic activities, but also those that remained unaltered during the analyzed period.

Coordinates of the 235 caves within the study area were plotted on the maps to assess the landscape composition and configuration [48] in the speleological context. The Brazilian legislation established a protection radius of $250 \mathrm{~m}$ around the caves until specific studies determine the necessary protection perimeter [54]. Therefore, vectors with $250 \mathrm{~m}$ radius (buffers) were determined considering the legal requirements around each plotted cave and clipped in the LULC maps in order to analyze the landscape around such features applying metrics based on concepts of landscape ecology $[22,29]$. Such metrics refer to the area that each class occupies in the respective LULC maps and the spatial location of changes observed in the landscape from 1984 to 2015.

\section{Results}

\subsection{Landscape evolution in the study area}

The result of image classification generated an overall accuracy of $87.85 \%$ (1984) and 93.72 (2015) and a Kappa value of 0.78 (1984) and 0.91 (2015), which means that the classification was satisfactory [47]. The application of landscape metrics in the LULC maps (Fig. 2) demonstrates that, in general, the conservation status of the region decreased due to the increase in areas impacted by anthropic activities. The native vegetal cover that anteriorly occupied $88.71 \%$ of all the extension reduced to $66.57 \%$, while the area occupied by anthropic activities showed an almost threefold increase, varying from 10.51 to $32.56 \%$ (Table 1).

The vegetal cover by herbaceous species (Fig. 3) was the dominant class in both 1984 and 2015, currently occupying only $39.37 \%$ of the landscape, against $51.67 \%$ observed in the past. Attention should also be drawn to the class represented by mining areas (Fig. 4), which occupies $17.31 \%$ of the total area in the present. Analyzing the data in Table 1, it can be observed that in this period, mining was the anthropic activity that presented the largest area increase (12.69\%), from 2474.58 ha to 9266.84 ha. Two points should be highlighted concerning mining: the first refers to the significant increase in the average size of the patches that previously comprised 82.49 ha and currently exceed 240 ha; the second is the $9 \%$ increase in the area occupied by water due to the construction of new tailings dams.

The vegetation cover is one of the primordial factors for the maintenance of the subterranean ecosystems, and 
Fig. 21984 and 2015 LULC maps
Table 1 Landscape metrics of the study area

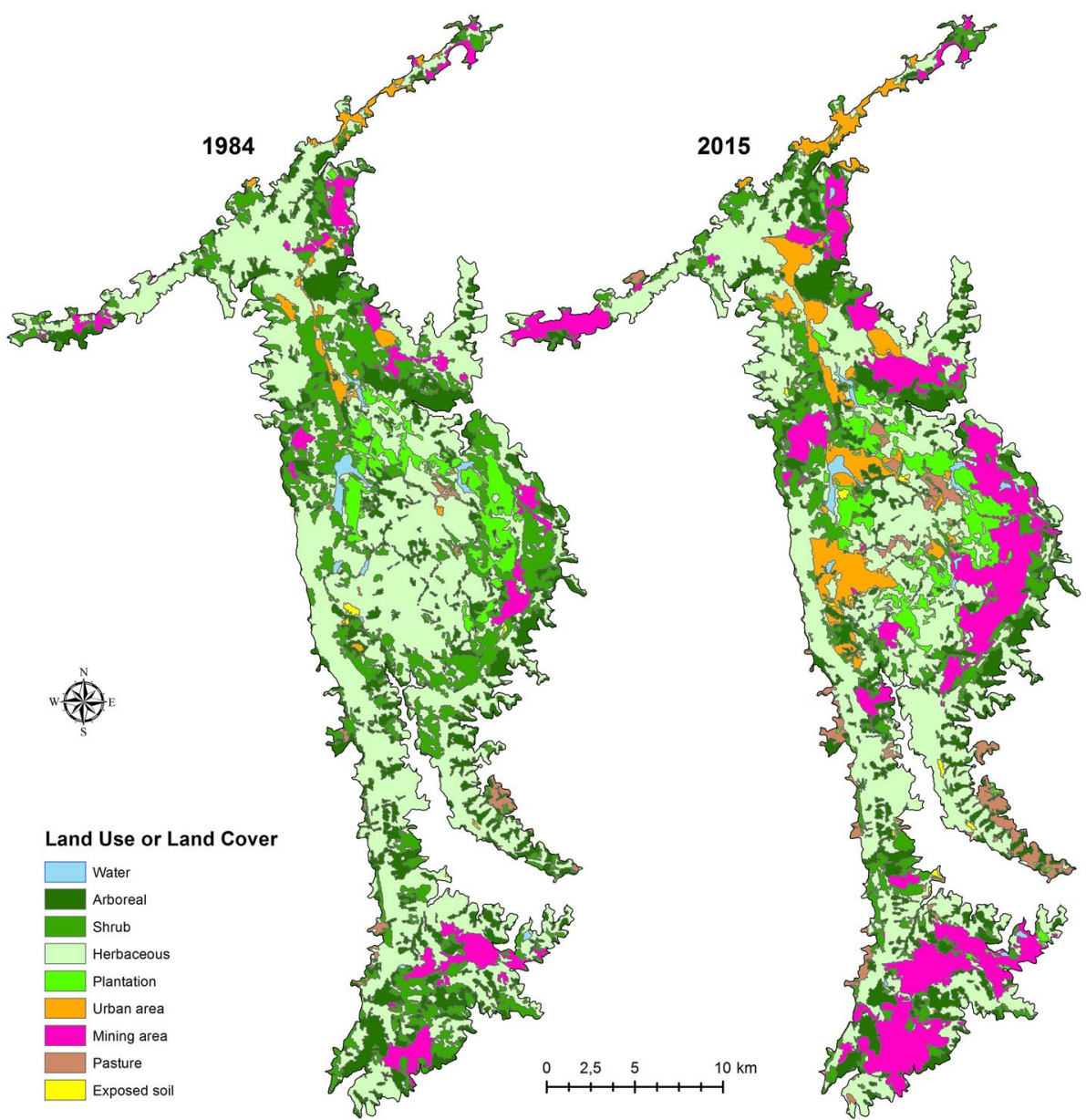

\begin{tabular}{|c|c|c|c|c|c|c|c|c|}
\hline \multirow[t]{2}{*}{ Classes } & \multicolumn{2}{|c|}{ Patches } & \multicolumn{2}{|l|}{ Area (ha) } & \multicolumn{2}{|c|}{$\begin{array}{l}\text { Mean area of } \\
\text { patches (ha) }\end{array}$} & \multicolumn{2}{|c|}{$\%$ Total area } \\
\hline & 1984 & 2015 & 1984 & 2015 & 1984 & 2015 & 1984 & 2015 \\
\hline Herbaceous vegetation & 228 & 200 & $27,667.85$ & $21,077.05$ & 121.35 & 105.39 & 51.67 & 39.37 \\
\hline Shrubby vegetation & 272 & 270 & $10,146.11$ & 6182.49 & 37.30 & 22.90 & 18.95 & 11.55 \\
\hline Arboreal vegetation & 405 & 379 & 9687.13 & 8382.51 & 23.92 & 22.12 & 18.09 & 15.66 \\
\hline Exposed soil & 9 & 28 & 103.24 & 222.73 & 11.47 & 7.95 & 0.19 & 0.42 \\
\hline Forestry & 40 & 68 & 2064.86 & 3015.21 & 51.62 & 44.34 & 3.86 & 5.63 \\
\hline Pasture & 26 & 73 & 371.18 & 1580.48 & 14.28 & 21.65 & 0.69 & 2.95 \\
\hline Urban area & 20 & 35 & 614.83 & 3349.09 & 30.74 & 95.69 & 1.15 & 6.26 \\
\hline Mining area & 30 & 38 & 2474.58 & 9266.84 & 82.49 & 243.86 & 4.62 & 17.31 \\
\hline Water & 9 & 18 & 414.38 & 461.53 & 46.04 & 25.64 & 0.77 & 0.86 \\
\hline
\end{tabular}

for this reason, qualitative and quantitative analyzes were performed to evaluate the spatial allocation dynamics of the changes in the landscape. Figure 5 shows the composition of the native vegetation that was removed and the respective anthropic class that replaced it.

Figure 5 shows, in percentage values, how much of the area originally occupied by native vegetation was replaced by anthropogenic activities. In the case of the mining area which increased by 6792.26 ha (Table 1), it was verified that there was a loss of $24.63 \%$ of shrub, $10.59 \%$ herbaceous and $8.79 \%$ arboreal vegetation (Fig. 5).

\subsection{Landscape evolution $250 \mathrm{~m}$ around the caves}

The clip made in LULC maps using the $250 \mathrm{~m}$ buffer allowed segmenting information related to the landscape 


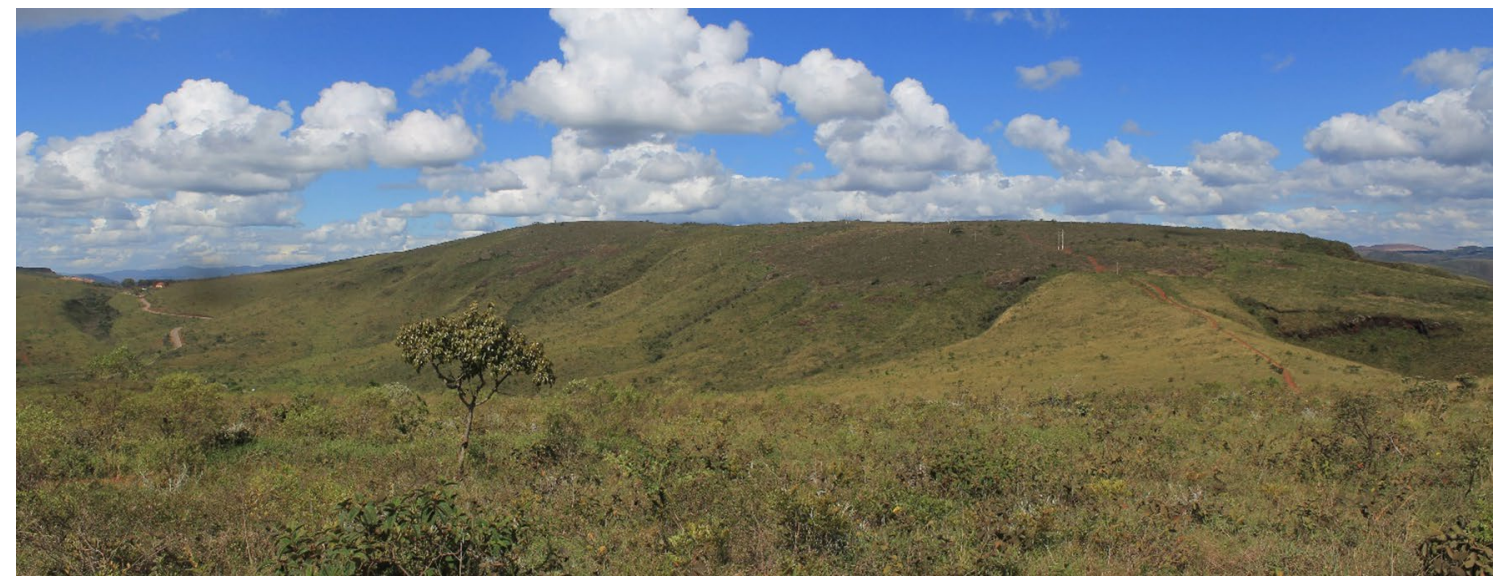

Fig. 3 Example of Herbaceous vegetation in study area. Serra do Rola-Moça State Park, Nova Lima municipality, Minas Gerais. Author's photograph on April 13, 2016

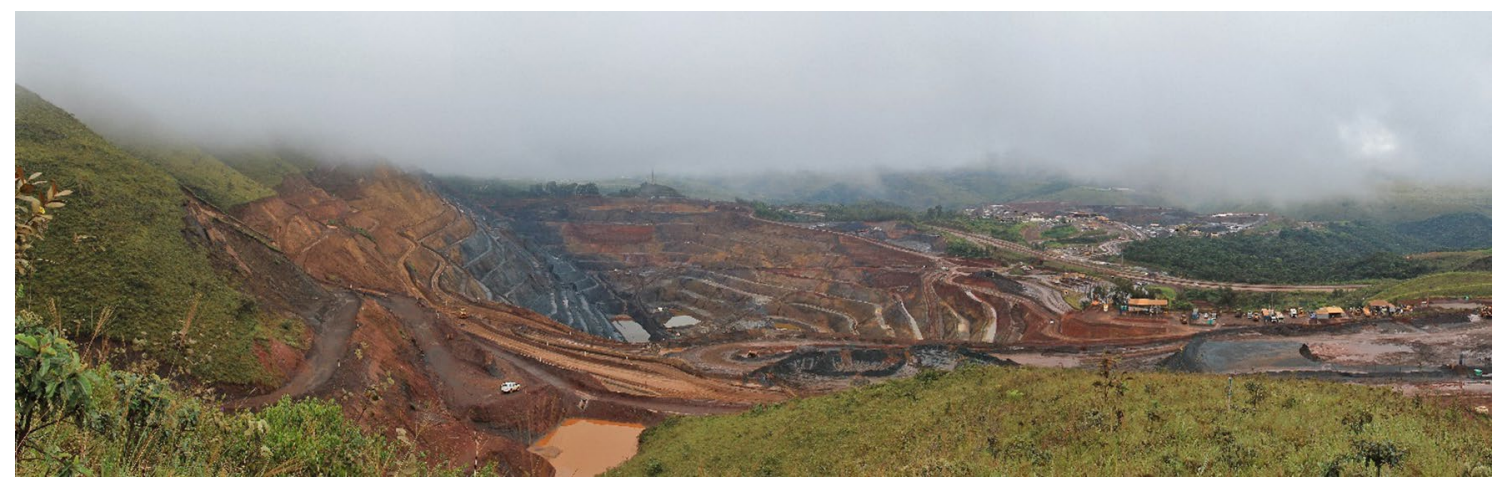

Fig. 4 Example of iron ore mine in study area, Itabirito municipality, Minas Gerais. Author's photograph on March 20, 2017

composition, considering only the surroundings of caves (Table 2).

In $1984,94.73 \%$ of the cave surroundings was occupied by native vegetation, with predominance of herbaceous vegetation (56.19\%). In that time, only two anthropic activities were observed around the caves: mining, occupying $5.05 \%$ of the area, and urban patches, that represented $0.22 \%$ of the area. On the other hand, in 2015 the stratification identified that the landscape around the caves is more degraded, since currently only $79.01 \%$ of the native cover remained, with predominance of herbaceous vegetation $(47.85 \%)$. The increase in areas impacted by mining at less than $250 \mathrm{~m}$ of the cave entrances is significant, besides several areas of exposed soil. These activities, that previously occupied $5.05 \%$ of the landscape, now are present at $20.18 \%$ of the areas. The increase in mean size of patches is also relevant, which changed from 11.68 ha to 38.86 ha.

The expansion of areas occupied by mining from 1984 to 2015 has almost eliminated the protection radius of 36 caves, as demonstrated in the present study, although the suppression of some of these features was authorized by the competent institutions [62]. However, it is not possible to affirm that only these caves were impacted, since until the beginning of the 2000s the speleological heritage in ferruginous rocks was almost unknown $[58,59]$. The results of the present research also identified that besides those caves without any vegetal cover surrounding them, others do not present the significant vegetal cover. In this scenario, three caves, which have been strongly threatened by mining activities, must be especially mentioned: the caves MP-014 and MP-017 that harbor the troglobitic harvestmen Gonycranaus pluto [6] and MP-008, the only known habitat of the rare and endemic planthopper Ferricixius davidi [38]. According the authors, this is one of the planthoppers most adapted to the subterranean lifestyle among described species. Figure 6 presents the result of the analysis of landscape evolution around MP-008 cave, highlighting the replacement of native vegetation by mining. Ferricixius davidi is rhizophagous (i.e., it feeds exclusively on

\section{SN Applied Sciences}




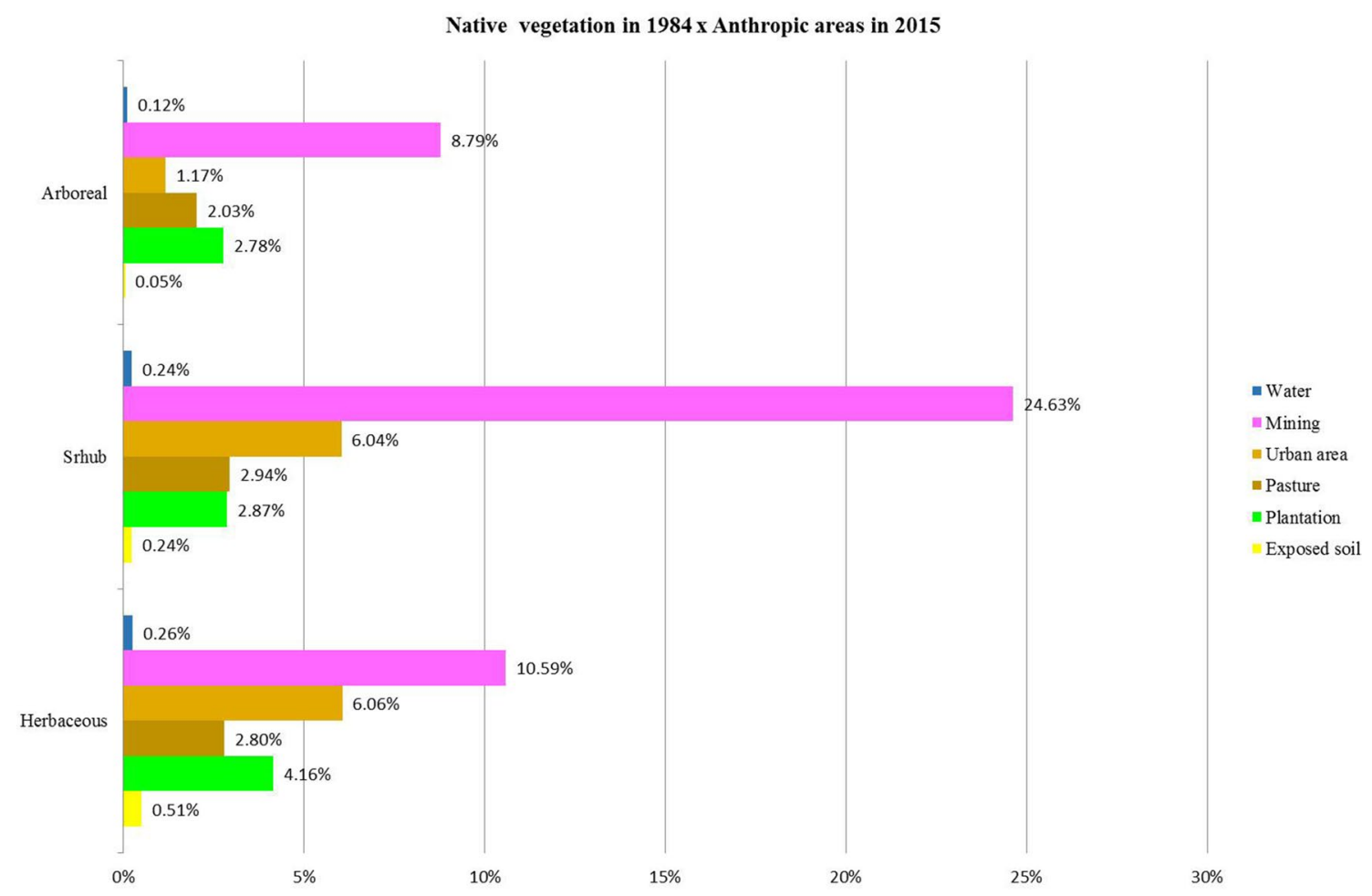

Fig. 5 Conversion of native vegetation into anthropic areas from 1984 to 2015

Table 2 Landscape metrics of 250-m buffers around caves

\begin{tabular}{|c|c|c|c|c|c|c|c|c|}
\hline \multirow[t]{2}{*}{ Classes } & \multicolumn{2}{|c|}{ Patches } & \multicolumn{2}{|l|}{ Area (ha) } & \multicolumn{2}{|c|}{$\begin{array}{l}\text { Mean area of } \\
\text { patches (ha) }\end{array}$} & \multicolumn{2}{|c|}{$\%$ Total area } \\
\hline & 1984 & 2015 & 1984 & 2015 & 1984 & 2015 & 1984 & 2015 \\
\hline Herbaceous vegetation & 28 & 30 & 1298.63 & 1105.84 & 46.38 & 36.86 & 56.19 & 47.85 \\
\hline Shrubby vegetation & 27 & 30 & 590.65 & 418.23 & 21.88 & 13.94 & 25.56 & 18.09 \\
\hline Arboreal vegetation & 37 & 44 & 299.97 & 301.71 & 8.11 & 6.86 & 12.98 & 13.06 \\
\hline Exposed soil & - & 1 & - & 1.99 & - & 1.99 & - & 0.09 \\
\hline Urban area & 3 & 4 & 5.03 & 16.82 & 1.68 & 4.21 & 0.22 & 0.73 \\
\hline Mining area & 10 & 12 & 116.81 & 466.27 & 11.68 & 38.86 & 5.05 & 20.18 \\
\hline
\end{tabular}

The spatial analysis of landscape alterations highlighted that the distance between anthropic activities and caves decreased due to the loss of vegetal cover in such features. Figure 7 presents the distribution of distance between these caves and anthropic activities, and comparing the data from 1984 and 2015, a degradation is observed in the protection radius of the caves due to an increase in the number of caves with a radius of less than $250 \mathrm{~m}$.

Figure 7 shows that in 1984, 52 caves were at a distance greater than $250 \mathrm{~m}$ from anthropic activity and in 2015 this distance is observed for 3 caves only. Data classified as distance " 0 " in Fig. 7 refer to caves located in areas completely affected by mining activities. In 1984, three caves were identified and, in addition to these, another three were identified in the same conditions in 2015. The spatial unfavorable for the conservation of speleological heritage. 

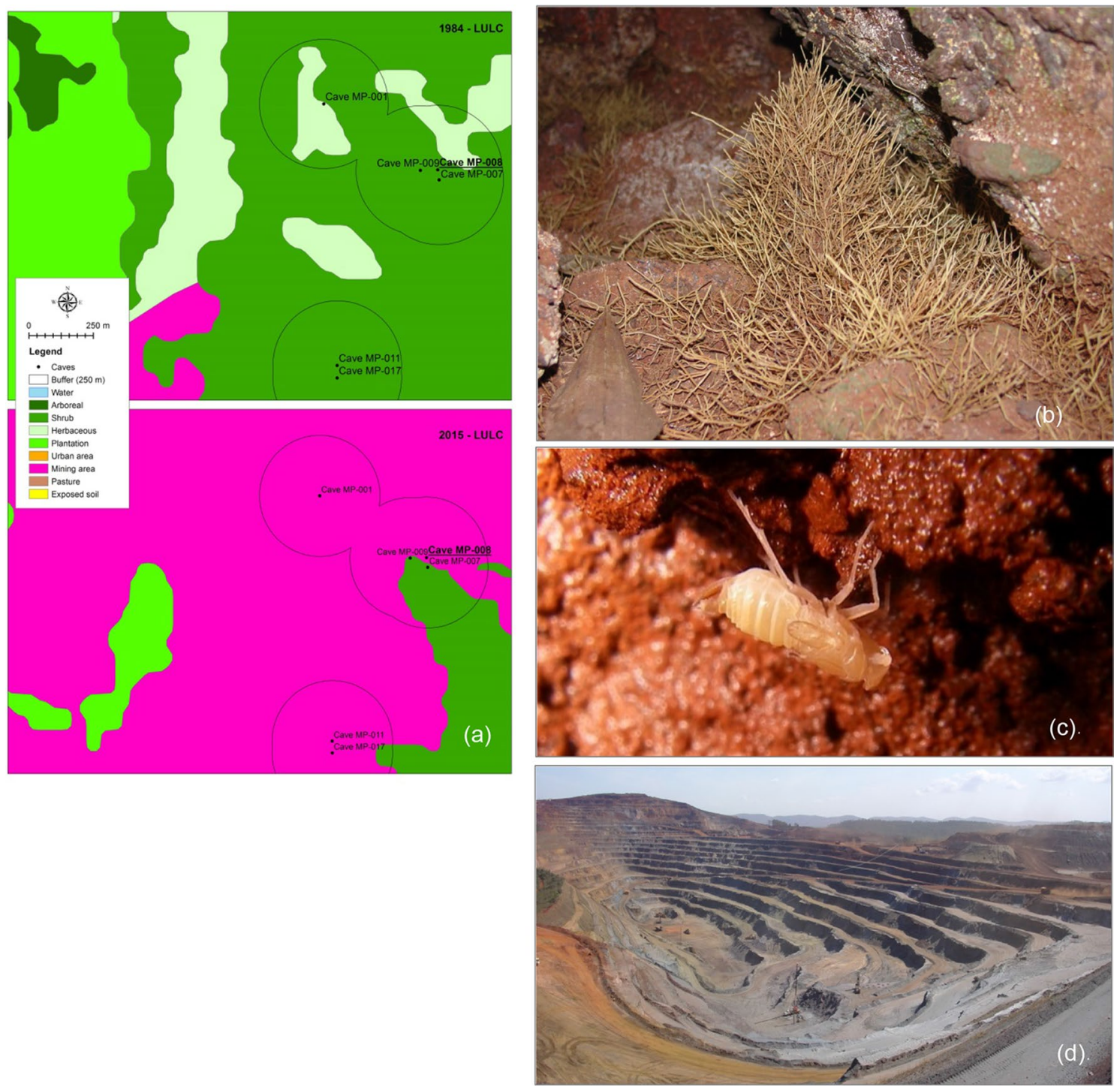

Fig. 6 LULC around MP-008 cave in 1984 and 2015 (a); root carpet in the MP-008 cave (b); Ferricixius davidi (c); mine (d). Photographs: b-d [38]

analysis also pointed that the reduction of the protection radius of the 75 caves was caused by mining activities around 68 caves, urbanization around 4 and exposed soil around 3 caves.

\section{Discussion}

Scientific studies have been demonstrating that anthropic alterations in the vegetal cover and land use may impact negatively ecological processes and the biodiversity [37, $45,51,55]$. The increase in mining activities and urban expansion in the last years have been altering significantly the landscape of Iron Quadrangle in Brazil, improving the threats to the vegetal cover of ferruginous fields $[44,45]$.
As pointed up by Ferreira [26], such cover represents the main energetic contribution to the subterranean ecosystems found in the iron ore caves. The reduction in such contribution by anthropic activities, as demonstrated in the present work, may affect irreversibly several cave species of the FGs, especially those restrict to such habitats, namely troglobites [13], as the specie described by Hoch and Ferreira [38] in one of the caves of the study area.

The analysis of the data related to the native vegetation during the studied period (Table 1) indicated a significant reduction in the conservation status in the area, which lost $22.14 \%$ of the natural vegetal cover. There is a less notable increase in the number of urban and mining fragments but a substantial increase in the size of these areas (Table 1 and Fig. 2) influenced mainly by the development of the

\section{SN Applied Sciences}


Proximity of anthropic activities from cave entrances

60

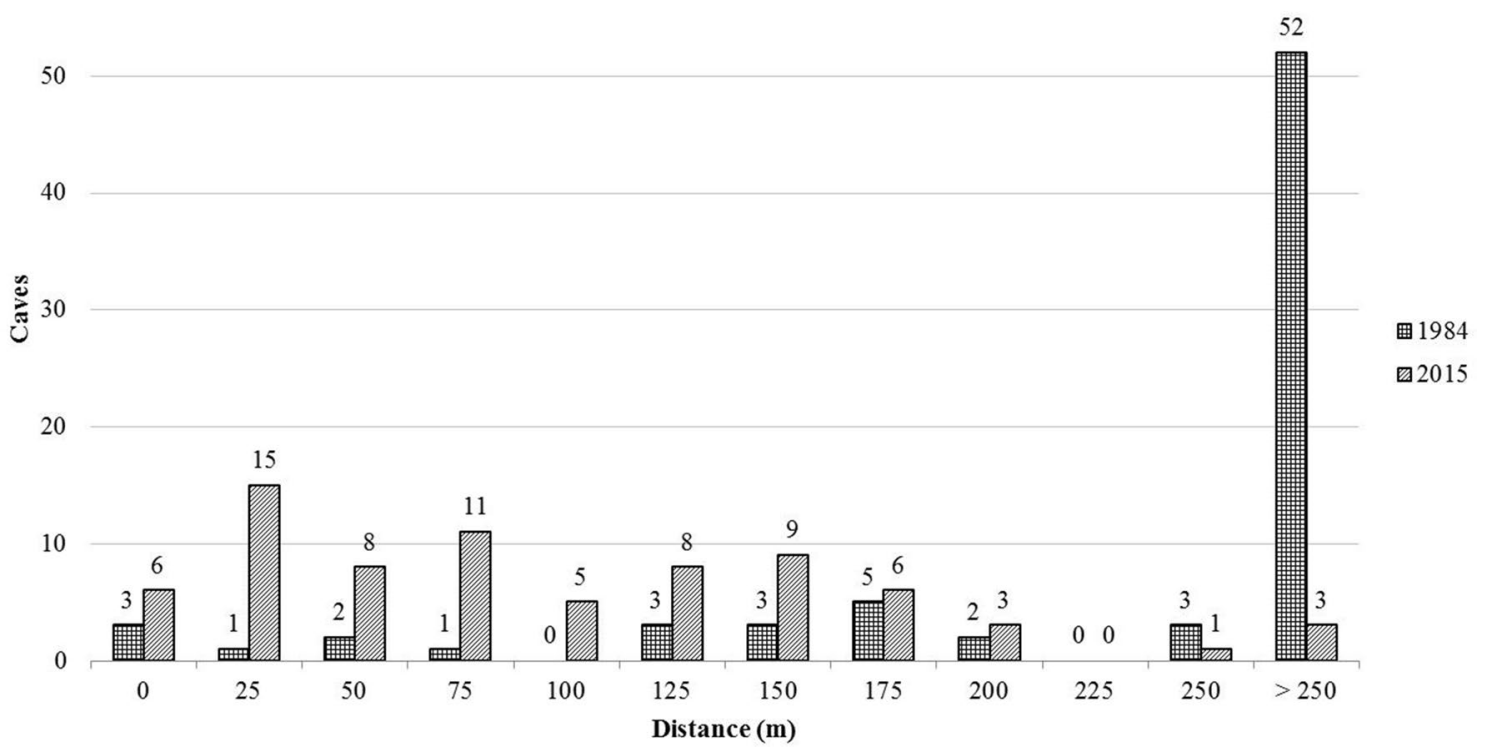

Fig. 7 Caves and respective distance between their entrance and anthropic areas considering 250-m buffers

metropolitan region of the city of Belo Horizonte $[53,74]$ and the global iron ore market [73]. This study indicates that these changes in the landscape occurred mainly due to the expansion of regions previously occupied by these activities. However, it was observed that the other anthropic areas presented a different model of landscape evolution. These activities were identified in a more dispersed way in the study area, increasing the fragmentation of the natural vegetation cover [33] due to the increase in the number of patches and occupied area. In some cases (exposed soil and forestry), the decrease in the average value of the occupied areas was observed. The forestry activity in the study area, which is also closely related to the global demand for steel [69], experienced a 58.82\% increase in the number of patches. The exposed soil, for example, raised more than $200 \%$, changing from 9 to 28 . Pasture areas increased from 26 to 73 , and those occupied by water-almost all of them representing mining tailing dams-doubled from 9 to 18.

Regarding the mining tailing dams, the main alterations in the landscape occur when such structures are installed, when accumulated tailings may reach the altimetric quota where caves are located, thus causing impacts to their area of influence or even their complete burial. However, recent tragedies that occurred in the region of Iron Quadrangle due to the disruption of the tailings dam of Fundão, in the municipality of Mariana in 2015 [25] and the dam of Córrego do Feijão in Brumadinho in 2019 point to the risk that caves downstream the dams are subject to. In the case of Mariana, there are no specific studies quantifying the damages caused by the speleological heritage, but some news [17] indicate that several caves suffered irreversible impacts in function of the mud spill. In the case of Brumadinho, four caves are located less than $10 \mathrm{~m}$ away from the Paraopeba River, the main stream affected by the release of mining tailings (Fig. 8), and probably had their area of influence impacted.

Regarding the spatial allocation of the main classes of anthropized areas (mining and urban areas), two distinct patterns of growth were observed. Little changes were identified around already populated areas, although the number of urban patches increased in areas where such class of occupancy had not been observed in 1984 (20-35, 57\% larger). It is important to highlight that the study area is situated in the metropolitan region of Belo Horizonte, the capital of the state of Minas Gerais, which represents the third largest urban agglomeration of Brazil, with almost five million people [74]. The wide distribution of urban patches in the landscape not only remove the vegetal cover, but also compromise its integrity by favoring the occurrence of forest fires caused by men $[12,18$, $52]$, which are frequent in the region and affect large areas of native vegetation.

The second pattern of landscape evolution that must be highlighted is the vegetal suppression around areas already occupied in 1984 by mining. Differently from those alterations caused by urban patches, this change in land cover was mainly characterized by the expansion of 


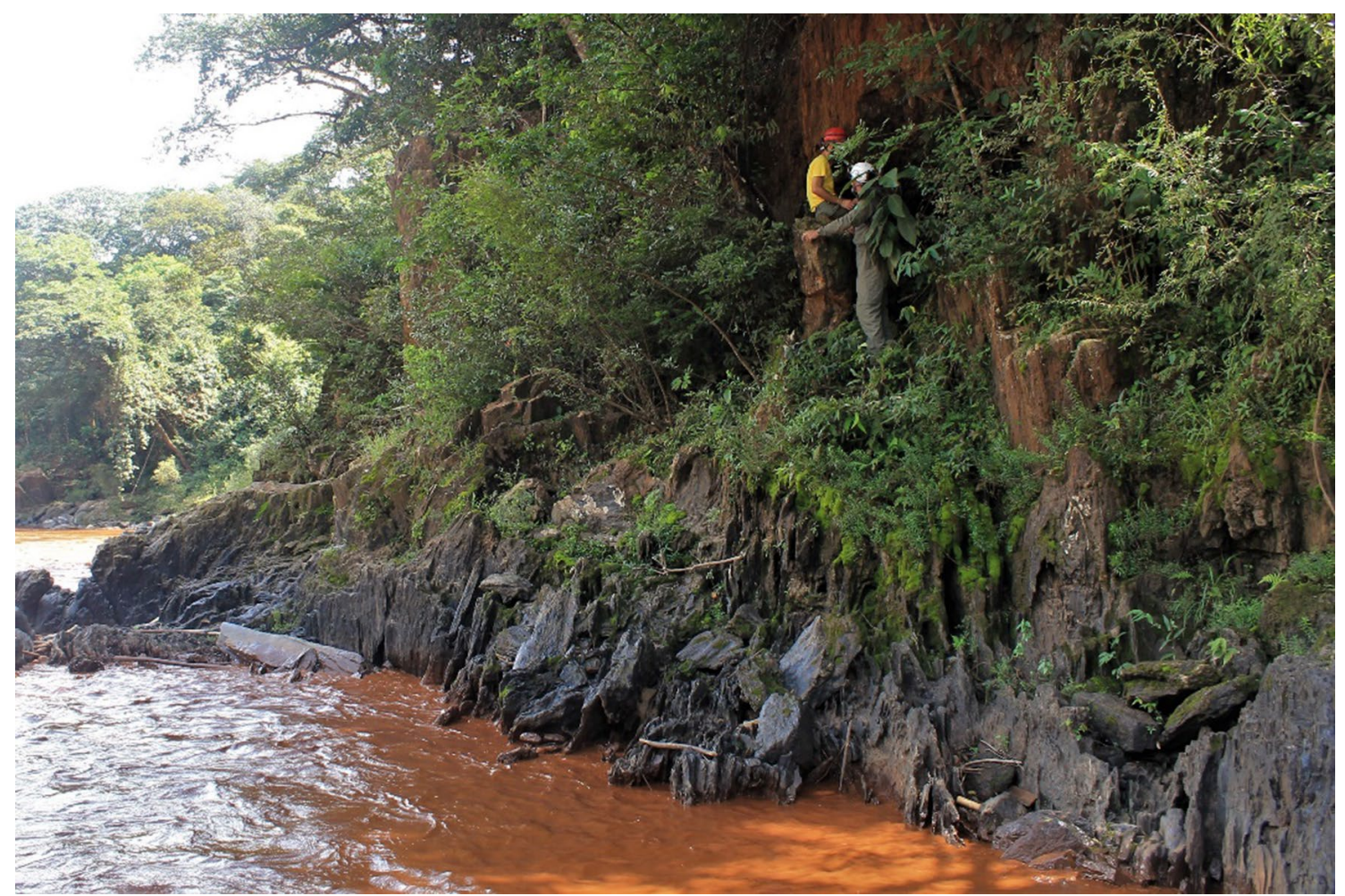

Fig. 8 Speleologists in front of the Fecho do Funil III Cave entrance located on the banks of the Paraopeba River, Brumadinho municipality, Minas Gerais. Author's photograph on February 05, 2019

previously explored areas, and not due to the emergence of new areas of exploration. This observation is in accordance with data from the metrics of the study area, which recorded the emergence of only eight new patches related to mining areas and a significant increase in the mean size of patches from 82.49 to $243.86 \mathrm{ha}$.

Changes in land cover in mining areas have stimulated the development of researches in several countries such Australia [31], India [30, 61], Canada [50], China [36], Ghana $[4]$ and also in Brazil $[69,70]$. As presented in this paper, the results of those surveys reveal the substitution of native vegetation cover by pits, tailings dams and others mining facilities, but none of them specifically addresses the issue of impacts to speleological heritage. The expressive increase in mining areas reflects the increasingly world demand by iron ore [73], which pressured the Brazilian government to adopt less restrictive measures in relation to the protection of the speleological heritage to avoid making the mining extraction unfeasible [3]. These authors also stated that, although the federal law was extremely restrictive until the beginning of the 2000s, many caves were suppressed without any previous scientific study. Only as from 2004 [54], specific studies started to be required to obtain environmental licenses, and even more recently, in 2008, the caves started to be classified into different relevance degrees [7]. Caves with high, medium or low relevance are allowed to be suppressed in the case that previous studies are favorable to such measure.

Pellegrini et al. [57] highlighted the importance of conserving the landscape around caves for the maintenance of subterranean ecosystems. Caves associated with ferruginous rocks may present high species richness [67] when compared to caves of the same dimensions in other lithologies due to the existence of an intricated network of subterranean connections. The extensions and number of these systems are directly related to the availability and variety of habitats, which contributed significantly to the maintenance of a high species richness. Ferreira et al. [27] also pointed out the presence of canaliculi as an important characteristic of ferruginous caves, since they promote subsurface connections among caves and between caves and surface, thus allowing the transit of organisms. In this sense, it is possible to infer that the compromise of the surrounding areas of a cave may reflect in other features that have not had their protection radius directly affected by anthropic actions.

Little is known on the behavior of cave fauna regarding alterations occurring in the area of influence of caves. Moreover, there are few studies monitoring the subterranean fauna associated with the advances of mining activities around the caves, which are restricted to the processes of environment licensing, that offer few or

\section{SN Applied Sciences


any access to researchers. One of the few studies that allowed the access to information about such monitoring revealed that "the advance of mining areas affected significantly the species richness" [71]. Other study indicated that the currently adopted methodologies to monitor the fauna do not provide conclusions on to what extent the subterranean environment is influenced by the growth of anthropic activities around the caves, especially mining [20].

\section{Final considerations}

Results obtained in the present study highlighted that the transformations occurring in the landscape caused by the replacement of native vegetal cover by anthropic activities, specifically mining and urbanization, should not be observed only under the perspective of surface changes. The vegetation removal in FGs may have irreversible effects on the complex cave ecosystems, that shelter highly specialized organisms, totally adapted to the subterranean lifestyle, mostly with small populations restrict to one cave.

The legal apparatus that allows and regulates the soil use, which also promotes the conservation of this rich and even unknown heritage, still has to be significantly improved to become a little closer to a utopic equilibrium point between development and conservation. The need to develop scientific studies considering the relationship between cave fauna and vegetal cover around the caves, as well as the consequences that anthropic activities may cause to the subterranean environment, is imminent. The knowledge on the landscape evolution through time may motivate the development, or at least improvement, of public policies related to the granting of authorizations to exploit natural resources, and mainly the systematics of monitoring the several conditions imposed to entrepreneurs during the process of environment licensing.

We hope that data generated in the present study contribute to discussions regarding the definition of criteria to determine the influence area of caves, as well as encourage processes of improvement, systematization and availability of information obtained by studies, providing support to decisions involving the environmental licensing.

Acknowledgements We would like to thank the National Institute of Space Research (INPE), which provided the Landsat images used to draw the map of vegetal cover and land use, through the Image Generation Division of Cachoeira Paulista/SP; the National Center for Research and Conservation of Caves (ICMBIO/CECAV); the National Council of Technological and Scientific Development (CNPQ-Grant $304682 / 2014-4)$; and the valuable suggestions of the reviewers, which helped improve the manuscript.

\section{Compliance with ethical standards}

Conflict of interest On behalf of all authors, the corresponding author states that there is no conflict of interest.

\section{References}

1. Auler AS (2006) Relevância de cavidades naturais subterrâneas - Contextualização, impactos ambientais e aspectos jurídicos. Ministério das Minas e Energia, Brasília, DF

2. Auler AS, Farrant AR (1996) A brief introduction to karst and caves in Brazil. Proc Univ Bristol Spelaeol Soc 20:187-200

3. Auler AS, Piló LB (2015) Caves and mining in Brazil: the dilemma of cave preservation within a mining context. In: Andreo B, Carrasco $F$, Durán JJ, Jiménez $P$, LaMoreaux JW (eds) Hydrogeological and environmental investigations in karst systems. Springer, Berlin, pp 487-496. https://doi.org/10.1007/978-3-642-17435 $-3 \_55$

4. Basommi PL, Guan Q, Cheng D (2015) Exploring land use and land cover change in the mining areas of Wa East District, Ghana using satellite imagery. Open Geosci 7:618-626. https://doi. org/10.1515/geo-2015-0058

5. Beato DAC, Monsores ALM, Bertachinni AC (2005) Projeto APA Sul RMBH - Estudos do meio físico - Hidrogeologia. Companhia de Pesquisa de Recursos Minerais - CPRM, Belo Horizonte, MG

6. Bragagnolo C, Hara MR, Pinto-da-Rocha R (2015) A new family of Gonyleptoidea from South America (Opiliones, Laniatores). Zool J Linn Soc 173:296-319. https://doi.org/10.1111/zoj.12207

7. Brasil (2008) Decreto $n^{\circ} 6.640$ de 07 de novembro de 2008. Brasília, DF

8. Butcher PA, McNee SA, Krauss SL (2009) Genetic impacts of habitat loss on the rare ironstone endemic Tetratheca paynterae subsp. paynterae. Conserv Genet 10:1735-1746. https://doi. org/10.1007/s10592-008-9775-y

9. Calux A, Cassimiro R, Salgado A (2019) Caves in iron formations in the Quadrilátero Ferrífero, Minas Gerais, southeastern Brazil: lithological, morphological and hydrological settings and speleogenesis. Z Geomorphol 62:125-144. https://doi.org/10.1127/ $\mathrm{zfg} / 2019 / 0475$

10. Cavalcanti LF (2018) Áreas prioritárias para a conservação do Patrimônio Espeleológico. Centro Nacional de Pesquisa e Conservação de Cavernas, Brasília, DF

11. CECAV (2016) Base de dados geoespacializados das cavernas do Brasil [WWW Document]. Centro Nacional de Pesquisa e Conservação de Cavernas. http://www.icmbio.gov.br/cecav/downl oads/mapas.html. Accessed 22 Nov 2018

12. Costa FV, Mello R, Lana TC, Neves FDS (2015) Ant fauna in megadiverse mountains: a checklist for the rocky grasslands. Sociobiology 62:228-245. https://doi.org/10.13102/sociobiolo gy.v62i2.228-245

13. Culver DC, Pipan T (2009) The biology of caves and others subterranean habitats. Oxford University Press, Oxford

14. de Medina AIM, Dantas ME, Saadi A (2005) Projeto APA SUL $\mathrm{RMBH}$ - Estudos do Meio Físico. Companhia de Pesquisa de Recursos Minerais - CPRM, Belo Horizonte

15. de Neves ACO, Nunes FP, de Carvalho FA, Fernandes GW (2016) Neglect of ecosystems services by mining, and the worst environmental disaster in Brazil. Nat Conserv 14:24-27. https://doi. org/10.1016/j.ncon.2016.03.002

16. de Souza FCR, do Carmo FF (2015) Geossistemas Ferruginosos no Brasil. Geossistemas Ferruginosos do Bras. 47-76

17. Desastre ambiental em Mariana (2016) G1 MG. Accessed: 14 Feb 2019 
18. do Carmo FF, Jacobi CM (2016) Diversity and plant trait-soil relationships among rock outcrops in the Brazilian Atlantic rainforest. Plant Soil 403:7-20. https://doi.org/10.1007/s1110 4-015-2735-7

19. Dorr JVN (1969) Physiographic, stratigraphic, and structural development of the Quadrilatero Ferrifero, Minas Gerais, Brazil. Geological Survey Professional Paper 110

20. Ecossistema (2015) OS 11/2014 - Aditivo - Monitoramento biológico e climático nas cavidades conforme previsto no Plano Básico Ambiental do Projeto Ferro Carajás S11D. Curitiba, PR

21. ERI (2017) Iron ore market study. Economic Research Institute ERI, Ulaanbaatar

22. Farina A (2006) Principles and methods in landscape ecology. Landscape Series. Springer, Dordrecht. https://doi. org/10.1007/978-1-4020-5535-5

23. FEAM (2010) Mapa de solos do Estado de Minas Gerais. Fundação Estadual Meio Ambient. FEAM

24. Fearnside PM (1989) The charcoal of Carajás: a threat to the forests of Brazil's Eastern Amazon region. Ambio 18:141-143

25. Fernandes GW, Goulart FF, Ranieri BD, Coelho MS, Dales K, Boesche N, Bustamante M, Carvalho FA, Carvalho DC, Dirzo R, Fernandes S, Galetti PM, Millan VEG, Mielke C, Ramirez JL, Neves A, Rogass C, Ribeiro SP, Scariot A, Soares-Filho B (2016) Deep into the mud: ecological and socio-economic impacts of the dam breach in Mariana, Brazil. Nat Conserv 14:35-45. https:// doi.org/10.1016/j.ncon.2016.10.003

26. Ferreira RL (2005) A vida subterrânea nos campos ferruginosos. O Carste 17:106-115

27. Ferreira RL, Oliveira MPA, Souza-Silva M (2015) Biodiversidade subterrânea em geossitemas ferruginosos. In: Carmo FF, Kamino LHY (eds) Geossistemas Ferruginosos Do Brasil: Áreas Prioritárias Para Conservação Da Diversidade Geológica e Biológica, Patrimônio Cultural e Serviços Ambientais. Instituto Prístino, Belo Horizonte, MG, pp 195-231. https://www.institutopristi no.org.br/wp-content/uploads/2016/03/Geossistemas-ferru ginosos-no-Brasil-CD.pdf

28. Ferreira RL, de Oliveira MP, Silva MS (2019) Subterranean Biodiversity in Ferruginous Landscapes. In: Moldovan O, Kováč L, Halse S (eds) Cave Ecology. Springer, Ecological Studies (Analysis and Synthesis), pp 435-447

29. Forman RTT, Godron M (1981) Components ecology landscape structural. Bioscience 31:733-740

30. Garai D, Narayana AC (2018) Land use/land cover changes in the mining area of Godavari coal fields of southern India. Egypt J Remote Sens Space Sci 21:375-381. https://doi.org/10.1016/j. ejrs.2018.01.002

31. Gibson N, Coates D, Van-Leeuwen S, Yates C (2015) Hot, dry and ancient: banded iron formations of western Australia. In: Carmo FF, Kamino LHY (eds) Geossistemas Ferruginosos Do Brasil: Áreas Prioritárias Para Conservação Da Diversidade Geológica e Biológica, Patrimônio Cultural e Serviços Ambientais. Instituto Prístino, Belo Horizonte, MG, pp 361-391

32. Gomes M, Jansen DC, dos Santos DJ, Cavalcanti LF (2014) Análise preliminar dos Mapas de Vulnerabilidade do Patrimônio Espeleológico para as áreas cársticas prioritárias da região de abrangência do PAN cavernas do São Francisco. Rev Bras Espeleol 1:10-51

33. Gomes M, Ruchkys ÚA, Ferreira RL, Goulart FF (2019) Landscape fragmentation around ferruginous caves of the Iron Quadrangle, Minas Gerais, Brazil. Cuad Geogr Rev Colomb Geogr 28:89-101. https://doi.org/10.15446/rcdg.v28n1.67506

34. González SA, Stotz W, Lancellotti D (2014) Effects of the discharge of iron ore tailings on subtidal rocky-bottom communities in Northern Chile. J Coast Res 295:500-514. https://doi. org/10.2112/JCOASTRES-D-12-00086.1

35. Google (2013) Google Earth
36. Guan C, Zhang B, Li J, Zhao J (2017) Temporal and spatial changes of land use and landscape in a coal mining area in Xilingol grassland. IOP Conf Ser Earth Environ Sci 52:1-8. https ://doi.org/10.1088/1755-1315/52/1/012052

37. Hansen AJ, DeFries R (2007) Ecological mechanisms linking protected areas. Ecol Appl 17:974-988

38. Hoch H, Ferreira RL (2012) Ferricixius davidi gen. n., sp. n. the first cavernicolous planthopper from Brazil (Hemiptera, Fulgoromorpha, Cixiidae). Mitteilungen aus dem Museum fur Naturkd. Berlin - Dtsch. Entomol Z 59:201-206. https://doi. org/10.1002/mmnd201200015

39. IBGE (2006) Mapa de Clima do Brasil. Instituto Brasileiro de Geografia e Estatística - IBGE, Rio de Janeiro

40. IBGE (2012) Manual Técnico da Vegetação Brasileira, Manuais técnicos em geociências. Instituto Brasileiro de Geografia e Estatística - IBGE, Rio de Janeiro, RJ. ISSN: 0101-4234

41. IBGE (2013) Manual técnico de uso da terra, Manuais técnicos em geociências. Instituto Brasileiro de Geografia e Estatística - IBGE, Rio de Janeiro, RJ

42. IBRAM (2018) Relatório Anual de Atividades - Julho de 2017 - Junho de 2018. Instituto Brasileiro de Mineração - IBRAM, Brasília, DF

43. INPE (2001) Introdução ao sensoriamento remoto. Instituto de Pesquisas Espaciais - INPE, São José dos Campos, SP

44. Jacobi CM, Carmo FF (2008) The contribution of ironstone outcrops to plant diversity in the Iron Quadrangle, a threatened Brazilian landscape. Ambio 37:324-326. https://doi. org/10.1579/0044-7447(2008)37\%5b324:TCOIOT\%5d2.0.CO;2

45. Jacobi CM, do Carmo FF, Vincent RC, Stehmann JR (2007) Plant communities on ironstone outcrops: a diverse and endangered Brazilian ecosystem. Biodivers Conserv 16:2185-2200. https://doi.org/10.1007/s10531-007-9156-8

46. Jansen DC, Cavalcanti LF, Lamblém HS (2012) Mapa de potencialidade de ocorrência de cavernas no Brasil, na escala 1:2.500.000. Rev Bras Espeleol 2:42-57

47. Landis JR, Koch GG (1977) The measurement of observer agreement for categorical data. Biometrics 33:159-174. https ://doi.org/10.2307/2529310

48. Lang S, Blaschke T (2009) Análise da paisagem com SIG. Oficina de Textos, São Paulo, SP

49. Larizzati JH, Marques ED, Silveira FV (2014) Mapeamento geoquímico do Quadrilátero Ferrífero e seu entorno, 1 st edn. Serviço Geológico do Brasil - CPRM, Rio de Janeiro

50. Latifovic R, Fytas K, Chen J, Paraszczak J (2005) Assessing land cover change resulting from large surface mining development. Int J Appl Earth Obs Geoinf 7:29-48. https://doi. org/10.1016/j.jag.2004.11.003

51. Laurance WF, Delamônica P, Laurance SG, Vasconcelos HL, Lovejoy TE (2000) Rainforest fragmentation kills big trees. Nature 404:836-836. https://doi.org/10.1038/35009032

52. Lavor $P$, van den Berg C, Jacobi CM, Carmo FF, Versieux LM (2014) Population genetics of the endemic and endangered Vriesea minarum (Bromeliaceae) in the Iron Quadrangle, Espinhaco Range, Brazil. Am J Bot 101:1167-1175. https:// doi.org/10.3732/ajb.1300388

53. Lobo C, Matos R, Cardoso L, Comini L, Pinto G (2015) Expanded commuting in the metropolitan region of Belo Horizonte: evidence for reverse commuting. Rev Bras Estud Popul 32:219233. https://doi.org/10.1590/S0102-30982015000000013

54. MMA (2004) Resolução $n^{\circ} 347$, de 10 de setembro de 2004. Conselho Nacional do Meio Ambiente - CONAMA, Brasília, DF

55. Muchai M, Lens L, Bennun L (2002) Habitat selection and conservation of Sharpe's longclaw (Macronyx sharpei), a threatened Kenyan grassland endemic. Biol Conserv 105:271-277. https://doi.org/10.1016/S0006-3207(01)00118-5 
56. Myers N, Mittermeier RA, Mittermeier CG, da Fonseca GAB, Kent $\mathrm{J}(2000)$ Biodiversity hotspots for conservation priorities. Nature 403:853-858. https://doi.org/10.1038/35002501

57. Pellegrini T, Sales LP, Aguiar P, Lopes Ferreira R (2016) Linking spatial scale dependence of land-use descriptors and invertebrate cave community composition. Subterr Biol 18:17-38. https ://doi.org/10.3897/subtbiol.18.8335

58. Piló LB, Auler AS, Martins FD (2015) Carajás National Forest: iron ore plateaus and caves in Southeastern Amazon. In: Vieira BC, Salgado AAR, Santos LJC (eds) Landscapes and landforms of Brazil. Springer, Dordrecht, pp 273-283. https://doi. org/10.1007/978-94-017-8023-0

59. Piló LB, Coelho A, Reino JCR (2015) Geoespeleologia em rochas ferríferas: Cenário atual e conservação. In: Carmo FF, Kamino LHY (eds) Geossistemas Ferruginosos Do Brasil: Áreas Prioritárias Para Conservação Da Diversidade Geológica e Biológica, Patrimônio Cultural e Serviços Ambientais. Instituto Prístino, Belo Horizonte, MG, pp 125-148

60. Pradhan P, Patra S (2014) Impact of iron ore mining on human health in Keonjhar District of Odisha. IOSR J Econ Finance 4:23-26

61. Prakash A, Gupta RP (1998) Land-use mapping and change detection in a coal mining area - A case study in the Jharia coalfield, India. Int J Remote Sens 19:391-410. https://doi. org/10.1080/014311698216053

62. Ribeiro AA (2015) Ameaças à conservação do Patrimônio Espeleológico brasileiro em canga e litologias ferríferas. In: Rasteiro MA, Sallun Filho W (eds) $33^{\circ}$ Congresso Brasileiro de Espeleologia. Sociedade Brasileira de Espeleologia, Eldorado, pp 635-644

63. Roeser MPH, Roeser AP (2010) O Quadrilátero Ferrífero - MG, Brasil: Aspectos sobre sua história, seus recursos minerais e problemas. Geonomos 18:33-37

64. Rosière CA, Chemale F Jr (2000) Brazilian iron formations and their geological setting. Rev Bras Geociências 30:274-278. https ://doi.org/10.25249/0375-7536.2000302274278

65. Ruchkys ÚDA, Travassos LEP, Rasteiro MA, Faria LE (2015) Patrimônio Espeleológico em Rochas Ferruginosas - Propostas para sua conservação no Quadrilátero Ferrífero, Minas Gerais. Sociedade Brasileira de Espeleologia, Campinas, SP

66. Salgado AAR, Carmo FF (2015) 'Quadrilátero Ferrífero': a beautiful and neglected landscape between the gold and iron ore reservoirs. In: Vieira BC, Salgado AAR, Santos LJC (eds) Landscapes and landforms of Brazil. World geomorphological landscapes. Springer, Dordrecht. https://doi.org/10.1007/978-94-017-8023-0
67. Silva MS, Martins RP, Ferreira RL (2011) Cave lithology determining the structure of the invertebrate communities in the Brazilian Atlantic Rain Forest. Biodivers Conserv 20:1713-1729. https ://doi.org/10.1007/s10531-011-0057-5

68. Solá MEC, Guimarães CM, Paiva JEM (2008) Patrimônio Natural e Cultural - Zoneamento Ecológico Econômico da Serra da Moeda: Uma contribuição para a sua conservação. Brandt Meio Ambiente, Belo Horizonte, MG

69. Sonter LJ, Barrett DJ, Soares-Filho BS, Moran CJ (2014) Global demand for steel drives extensive land-use change in Brazil's Iron Quadrangle. Glob Environ Change 26:63-72. https://doi. org/10.1016/j.gloenvcha.2014.03.014

70. Sonter LJ, Moran CJ, Barrett DJ, Soares-filho BS (2014) Processes of land use change in mining regions. J Clean Prod. https://doi. org/10.1016/j.jclepro.2014.03.084

71. Spelayon (2014) Relatório final - Monitoramento da fauna cavernícola - Projeto Viga (No. 75). Spelayon Consultoria, Belo Horizonte, MG

72. Steinweg, T., Schuit, A., 2014. Impacts of the global iron ore sector Impacts of the global iron ore sector - Case study: Altain Khuder in Mongolia. Amsterdam

73. Tuck CA, Xun S, Singerling SA (2017) Global iron ore production data; clarification of reporting from the USGS. Mining Engineering Magazine February 20-23

74. UNDP, IPEA, FJP (2014) Human development atlas in the Brazilian metropolitan regions

75. UNESCO (2005) Espinhaço range [WWW Document]. Biosphere Reserve Information. http://www.unesco.org/mabdb/br/brdir /directory/biores.asp?code=BRA+06\&mode=all. Accessed 22 Nov 2018

76. Vama SR, Chaudhari PR, Shanta S (2012) Impact of leaching from iron ore mines on terrestrial and aquatic environment. Int J Environ Sci 2:2378-2386. https://doi.org/10.6088/ijes.00202030119

77. WorldSteel (2015) Indirect trade in steel. Worldsteel Association https://doi.org/10.1016/j.matdes.2014.12.011

Publisher's Note Springer Nature remains neutral with regard to jurisdictional claims in published maps and institutional affiliations. 